\title{
Multiple Sclerosis-Like Symptoms in Mice Are Driven by Latent $\gamma$ Herpesvirus- 68 Infected B Cells
}

\author{
Ana Citlali Márquez, Iryna Shanina and Marc Steven Horwitz* \\ Department of Microbiology and Immunology, The University of British Columbia, Vancouver, BC, Canada
}

OPEN ACCESS

Edited by:

Jorge Matias-Guiu,

Complutense University of Madrid,

Spain

Reviewed by:

Anna Fogdell-Hahn, Karolinska Institutet (KI), Sweden

Fred Lühder,

University of Göttingen, Germany

*Correspondence:

Marc Steven Horwitz

mhorwitz@mail.ubc.ca

Specialty section:

This article was submitted to

Multiple Sclerosis and

Neuroimmunology,

a section of the journal

Frontiers in Immunology

Received: 16 July 2020

Accepted: 21 October 2020

Published: 19 November 2020

Citation:

Márquez AC, Shanina I and Horwitz MS (2020) Multiple

Sclerosis-Like Symptoms in

Mice Are Driven by Latent

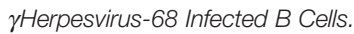

Front. Immunol. 11:584297. doi: 10.3389/fimmu.2020.584297
Multiple sclerosis (MS) is caused by a combination of genetic and environmental factors. It is believed that previous infection with Epstein Barr Virus (EBV) plays an important role in the development of MS. Previously, we developed a murine model where latent infection with gamma herpesvirus 68 ( $\gamma \mathrm{HV}-68)$, a murine homolog to EBV, enhanced the symptoms of experimental autoimmune encephalomyelitis (EAE), resulting in disease that more closely resembles MS in humans. Here, we explored the conditions that were necessary for EAE enhancement. We showed that latently infected CD19+1gD- B cells were capable of enhancing EAE symptoms when transferred from mice previously infected with $\gamma \mathrm{HV}-68$ into uninfected mice. We also observed a prevention of enhancement when B cells were depleted before infection. However, depletion after the establishment of latency only partially reduced EAE. This indicated the existence of a mechanism where B cells play an important role as antigen presenting cells (APCs) prior to EAE induction for the priming of Th1 cells. It is possible that these signals persist even after B cell depletion, strongly suggesting a paracrine signaling modulation of non-B cell APCs. These results strongly support the concept that EBV contributes to the development of autoimmunity and highlights the need for a vaccine against EBV that could limit or prevent multiple sclerosis development.

Keywords: multiple sclerosis, Epstein-Barr Virus, EAE, $\gamma \mathrm{HV}$-68, environmental factors, B cells

\section{INTRODUCTION}

Multiple sclerosis (MS) is a chronic inflammatory disease of the central nervous system (CNS) that affects more than 2.2 million people worldwide (1). As with many autoimmune diseases, the etiology of MS is largely unknown, although a combination of genetic elements (2-5) and environmental factors, including vitamin D deficiency, early-life obesity, gut dysbiosis, smoking, and infections have been associated with MS development (6-11).

Previous infection with Epstein-Barr Virus (EBV) is amongst the most prominent viral infections associated with contributing to the development of MS or the worsening of MS progression (12-15). Virtually $100 \%$ of MS patients are infected with EBV, and a history of infectious mononucleosis (a syndrome of EBV infection), increases the risk of developing MS later in life $(16,17)$.While this evidence strongly suggests that EBV contributes to MS development, the mechanism of EBV involvement in the pathogenesis of MS has been largely elusive. 
Before the introduction of $\mathrm{B}$ cell depletion therapies with monoclonal $\alpha$-CD20 antibodies (Rituximab/Ocrelizumab), it was thought that the role of $\mathrm{B}$ cells in MS was limited to the generation of autoantibodies (18). CD20 is a surface molecule present throughout the maturation cycle of B cells, from pre-B cells to memory cells, but not expressed on plasma cells (19). This discrepancy has caused a surge in the study of the antigen presentation ability of B cells (19-24).

Previously, our lab described an experimental model that largely mimics MS symptoms (25). Using murine gammaherpesvirus-68 $(\gamma \mathrm{HV}-68)$, a rodent homolog of EBV (26), and Experimental Autoimmune Encephalomyelitis (EAE), we have been able to show that latent infection with $\gamma \mathrm{HV}-68$ leads to a high number of $\mathrm{CD}^{+}$and $\mathrm{CD}^{+} \mathrm{T}$ cells infiltrating the CNS of mice induced with EAE. These immune cells produce an overwhelming Th1 response that leads to the enhancement of EAE clinical symptoms (25). Importantly, this enhanced response to EAE requires the virus to remain latent (27). When EAE is induced during acute $\gamma \mathrm{HV}-68$ infection, the start of EAE symptoms is delayed until most of the virus is cleared and latency is established. Moreover, when mice are infected with a latency free virus, they do not show signs of EAE enhancement (27). The role of $\gamma \mathrm{HV}-68$ latency and how latently infected cells affect EAE development is not yet clearly understood.

Splenic B cells, particularly the marginal zone $\mathrm{CD} 9^{+} \mathrm{IgD}^{-} \mathrm{B}$ cells, which exhibit features of memory B cells, harbor most of the $\gamma \mathrm{HV}-68$ virus during long term latency (28). In humans, memory B cells are also the main reservoir of latent EBV (29). Prior work by the Speck group (28) demonstrated that a small number (approximately 1 in 700) $\mathrm{CD} 19^{+} \mathrm{IgD}^{-}$carry latent virus 6 weeks post-infection, these, are mature B cells, most likely memory B cells. By 6 months this number drops to 1 in 2000 $\mathrm{CD}_{19} \mathrm{IgD}^{-}$cells and is likely comparable to the number of latently infected B cells post EBV infection.

It is not clear in our model if the B cells infected with $\gamma \mathrm{HV}-68$ during latency are actively participating in the enhancement of EAE, and the mechanism of this enhancement is not well understood. Here we show that the transfer of latently infected memory B cells leads to the enhancement of EAE symptoms in uninfected mice, and that $\gamma \mathrm{HV}-68$ latency establishes a precondition where $B$ cells are pre-programmed towards a Th1 response even before EAE induction. As a model for how EBV acts as a co-factor in MS development, we propose that latent gammaherpesvirus infection of memory B cells is sufficient to modulate the immune system. This modulation presents as a strong Th1 response which leads to the development of enhanced EAE symptoms reminiscent of MS in our model.

\section{METHODS}

\section{Mice and Ethics Statement}

C57Bl/6 mice were obtained from the Jackson Laboratory and were bred and maintained in the animal facility at the University of British Columbia. All animal work was performed in accordance with the regulation of the Canadian Council for Animal Care. The protocol was approved by the Animal Care Committee (ACC) of the University of British Columbia (Protocols A17- 0105, A17-0184).

\section{Infections and EAE Induction}

Mice between 8 and 10 weeks of age were infected intraperitoneally (i.p.) with $10^{4} \mathrm{pfu} \gamma \mathrm{HV}-68$ WUMS strain (purchased from ATCC, propagated on BHK cells) or $200 \mu \mathrm{l}$ MEM media as a control. Mice between 3 and 8 weeks old were infected intranasally (i.n.) with 400 pfu $\gamma \mathrm{HV}-68$ WUMS strain or $15 \mu \mathrm{l}$ PBS as a control. EAE was induced at different time points post infection by injecting $100 \mu \mathrm{l}$ emulsified Complete Freund's

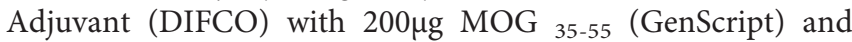
$400 \mu \mathrm{g}$ desiccated Mycobacterium tuberculosis H37ra (DIFCO) subcutaneously. Mice also received two doses of $200 \mathrm{ng}$ pertussis toxin (List Biologicals) via i.p. injection at the time of EAE induction and then again $48 \mathrm{~h}$ later. EAE was assessed on a score from 0 to 5 as follows: 0 , no clinical symptoms, 0.5 partially limp tail; 1 , paralyzed tail; 2 , loss of coordination; 2.5 , one hind limb paralyzed; 3, both hind limbs paralyzed; 3.5, both hind limbs paralyzed accompanied by weakness in the forelimbs; 4 , forelimbs paralyzed (humane endpoint); 5, moribund or dead.

\section{B-Cell Depletion}

$\mathrm{B}$ cell depletion was performed by injecting $50 \mu \mathrm{g} /$ day of $\alpha-\mathrm{CD} 20$ (clone 5D2 Genentech) i.v. for four consecutive days. Optimal depletion was confirmed by Flow Cytometry.

\section{Viral Quantification}

DNA was extracted from total splenocytes and enriched memory $\mathrm{B}$ cells (CD19 ${ }^{+} \mathrm{IgD}^{-}$negative selection) at indicated time points using either TRIzol Reagent (Invitrogen) or PureLink Genomic DNA Mini Kit (Invitrogen) following manufacturer's instructions. qPCR analysis of DNA samples was performed using $2 \times$ Quantitect Probe Mastermix (Qiagen, USA) on the BioRad CFX96 Touch ${ }^{\text {TM }}$ Real Time PCR Detection system with a final volume of $20 \mu \mathrm{l}$. Primers, probes and gBlocks ${ }^{\circledR}$ were obtained from Integrated DNA Technologies. Quantification of copies of mouse genome was done on $100 \mathrm{ng}$ of DNA by using primers and probe for a region of the mouse PTGER2 gene (Forward Primer: 5'-TACCTTCAGCTGTACGCCAC3'; Reverse Primer: 5'-GCCAGGAGAATGAGGTGGTC3'; Probe: 5'-/56-FAM/CCTGCTGCT/ZEN/TATCGTGGCTG/ 3IABkFQ/-3') (30) and absolutely quantified by use of a standard curve using concentrations from $5 \times 10^{7}$ copies/ $\mu$ lo $5 \times$ $10^{1}$ copies/ $\mu$ l. Quantification of copies of the $\gamma$-HV68 genome was done on $100 \mathrm{ng}$ of DNA by using primers and probe for a region of ORF50 (Forward Primer: 5'-TGGACTTTGAC AGCCCAGTA-3'; Reverse Primer: 5' - TCCCTTGAGGCA AATGATTC-3' ; Probe: 5' CTATGGCCAAGTCTTG/3IABkFQ/-3') and absolutely quantified by use of a separate standard curve using concentrations from $2 \times 10^{4}$ copies/ $\mu$ lo 2 copies/ $\mu$ l. Samples were run using a minimum of two technical replicates and all standard curves had an $\mathrm{R}^{2}$ greater than 0.95 . The protocol was as follows: $95^{\circ} \mathrm{C}$ for $15 \mathrm{~min}, 95^{\circ} \mathrm{C}$ for $15 \mathrm{~s}, 60^{\circ} \mathrm{C}$ for $1 \mathrm{~min}$, repeated 50 times. Quantification of copy number was done using the CFX 
manager software. The ratio of virus genome copy number to mouse genome copy number was obtained using the following equation:

$$
\begin{array}{r}
\frac{\text { copies of ORF50 }}{\text { copies of PTGER }} \chi \frac{2 \text { copies PTGER2/genome }}{\text { 1copyORF50/genome }} \\
\text { (simplified to } \left.\frac{\text { copies of ORF50 }}{\text { copies of PTGER2 }} \times 2\right) .
\end{array}
$$

\section{Immune Cell Isolation and Flow Cytometry}

Mice were euthanized 17 to 25 days post EAE induction depending on the severity of EAE in the mice. They were perfused with $30 \mathrm{cc}$ of PBS, and brains, spinal cords, and spleens were isolated. A single cell suspension was generated from each organ. Immune cells from the CNS were isolated using a 30\% Percoll gradient. For intracellular staining, CNS mononuclear cells, were stimulated for $4 \mathrm{~h}$ in DMEM (Gibco) containing 10\% FBS (Gibco), GolgiPlug (BD Biosciences), 10 ng/ml PMA, and $500 \mathrm{ng} / \mathrm{ml}$ ionomycin. Antibodies for the cell surface markers were added to the cells in PBS with $2 \%$ FBS for 30 min on ice. After washing, cells were resuspended in Fix/ Perm buffer (eBiosciences) for 30 to $45 \mathrm{~min}$ on ice, washed twice, and incubated with antibodies for intracellular antigens (cytokines and transcription factors) in Perm buffer (30 min, on ice). Fluorescently conjugated antibodies directed against CD4 (clone RM4-5), CD8 (clone 53-6.7), CD3 (clone eBio500A2), IFN- $\gamma$ (clone XMG1.2), Foxp3 (clone FJK-16s), and IL-17 (eBio17B7), CD19 (clone eBio1D3), IgD (clone 11-26c), RORyt (clone AFKJS-9), Tbet (clone eBio4B10), were all purchased from eBiosciences. Samples were acquired using a FACS LSR II (BD Biosciences) and analyzed using FlowJo software (Tree Star, Inc.).

\section{Adoptive Transfer}

Spleens from $\gamma \mathrm{HV}-68$ latently infected mice were isolated 5 weeks after initial infection, and a single cell suspension was prepared. Memory B cell enrichment was performed using a custom kit from STEMCELL Technologies that contained a combination of monoclonal antibodies, including $\operatorname{IgD}$, as negative selection antibodies. After enrichment, cells were washed in blank DMEM and were adjusted to a concentration of 1 to $1.5 \times 10^{6}$ cells/200 $\mu$ l. Cells were injected into naïve mice and, EAE was induced the following day as described above.

\section{Statistical Analysis}

Two-way ANOVA followed by Bonferroni's post-test was employed to compare EAE scores. Unpaired Student's t-test was used for all other analyses (GraphPad Prism). A p value of $<0.05$ was considered statistically significant.

\section{RESULTS}

\section{Transfer of CD19 ${ }^{+}$IgD- Cells From $\gamma \mathrm{HV}-68$ Infected Mice Can Lead to EAE Enhancement in Naïve Mice}

In order to determine whether memory B cells from $\gamma \mathrm{HV}-68$ infected mice have the ability to drive EAE enhancement, we infected mice with $\gamma \mathrm{HV}-68$, waited 5 weeks for the virus to undergo latency, then isolated $\mathrm{CD} 19^{+} \mathrm{IgD}^{-}$cells $(\gamma \mathrm{HV}-68 \mathrm{~B}$ cells) from spleen. Control mice were injected with Minimal Essential Medium (MEM) as a control (MEM B cell). We confirmed the presence of $\gamma \mathrm{HV}-68$ in $\gamma \mathrm{HV}-68 \mathrm{~B}$ cells by qPCR (Figure 1A). No $\gamma \mathrm{HV}-68$ was detected in $\mathrm{B}$ cells isolated from control mice. The $\mathrm{CD}_{19}{ }^{+} \mathrm{IgD}^{-} \mathrm{B}$ cells were adoptively transferred into naïve mice prior to induction of EAE. Previously, Willer and Speck (28) determined that $\mathrm{CD}_{1} 9^{+} \mathrm{IgD}^{-}$cells are the main reservoir of $\gamma \mathrm{HV}$ 68 during latency, at a ratio of $1 / 700$ infected $C D 19^{+} \operatorname{IgD}^{-}$cells at day 42 post infection. With this in mind, we transferred 1 to $1.5 \times 10^{6}$ cells per mouse, which would be roughly equivalent to between 1,400 and 2,000 $\gamma \mathrm{HV}-68$ infected cells per mouse. By day 17 postEAE induction, mice that had received $\gamma \mathrm{HV}-68 \mathrm{~B}$ cells reached humane endpoint and the experiment was terminated. We observed that, although not statistically significant, mice that had received $\gamma \mathrm{HV}-68 \mathrm{~B}$ cells had an overall higher EAE score (average 3 ) than mice that received MEM B cells (average 2) (Figure 1B). When we compared the level of $\mathrm{T}$ cell infiltration into the CNS of mice receiving $\gamma \mathrm{HV}-68 \mathrm{~B}$ cells compared to MEM B cells we found that there was a significant increase in $\mathrm{CD} 8^{+} \mathrm{T}$ cells in the brain $(\mathrm{p}<0.05)$ and spinal cord $(\mathrm{p}<0.05)$ of mice that received $\gamma \mathrm{HV}-68 \mathrm{~B}$ cells (Figure 1C). Although the $\mathrm{CD}^{+} \mathrm{T}$ cell infiltration is lower than what is observed in $\gamma \mathrm{HV}-68$ infected mice, it remains significantly higher than in MEM or MEM B cells mice $(\mathrm{p}<0.05)$ and is associated with increased clinical scores. Similar to what we had previously reported (25), there was no statistically significant difference in the infiltration of $\mathrm{CD}^{+} \mathrm{T}$ cells between mice that received $\gamma \mathrm{HV}-68 \mathrm{~B}$ cells and MEM B cells in both the brain and spinal cord (Figure 1D). This confirms that $\mathrm{CD}_{1} 9^{+} \mathrm{IgD}^{-} \mathrm{B}$ cells from $\gamma \mathrm{HV}-68$ mice are able to drive an increase in $\mathrm{CD}^{+} \mathrm{T}$ cell infiltrates into the CNS.

\section{$\gamma \mathrm{HV}-68$ B Cells Increase IFN $\gamma$ Production in T Cells Infiltrating the CNS}

In addition to strong $\mathrm{CD}^{+} \mathrm{T}$ cell infiltration into the CNS, we have previously observed that EAE enhancement during $\gamma \mathrm{HV}$ 68 latency is accompanied by a strong Th1 response, with $\mathrm{T}$ cells in the CNS producing high levels of IFN $\gamma$ and low levels of IL-17 compared to uninfected mice (25). To test if the presence of $\mathrm{CD}_{1} 9^{+} \mathrm{IgD}^{-}$cells from $\gamma \mathrm{HV}-68$ mice impacts the production of these cytokines, we used flow cytometry to detect IFN $\gamma$ and IL-17 in the brain and spinal cord of mice that received $\gamma \mathrm{HV}-68$ $\mathrm{B}$ cells versus those that received MEM B cells. We found that $\mathrm{CD}^{+} \mathrm{T}$ cells from mice with $\gamma \mathrm{HV}-68 \mathrm{~B}$ cells were producing similar amounts of IFN $\gamma$ in both brain and spinal cord than mice infected with $\gamma \mathrm{HV}-68$, and in quantities considerably higher than mice that received MEM B cells and MEM mice (Figure 1E). We also observed a marked downregulation of IL-17 produced by $\mathrm{CD} 4{ }^{+} \mathrm{T}$ cells in mice that received $\gamma \mathrm{HV}-68 \mathrm{~B}$ cells compared to those that received MEM B cells $(\mathrm{p}<0.01)$ and MEM mice $(\mathrm{p}<0.001)$ (Figure 1F), and at the same level as $\gamma \mathrm{HV}-68$ mice $(\mathrm{p}=\mathrm{ns})$.

One of the most significant changes during latency is the downregulation of Tregs in the periphery and CNS (27). When 


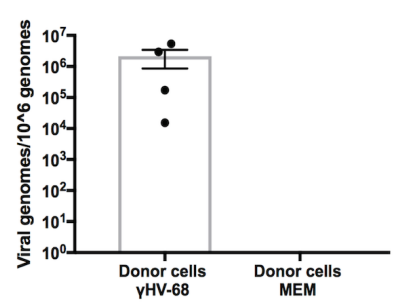

C
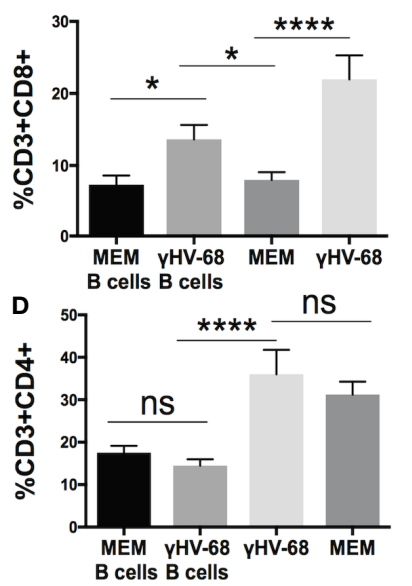

E

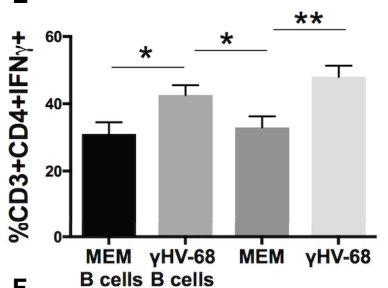

$F \quad B$ cells $B$ cells

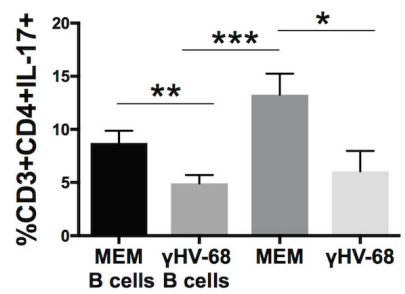

B

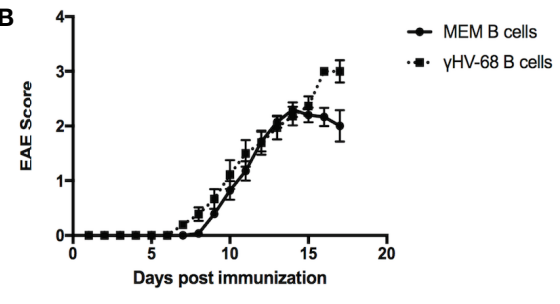

Spinal Cord
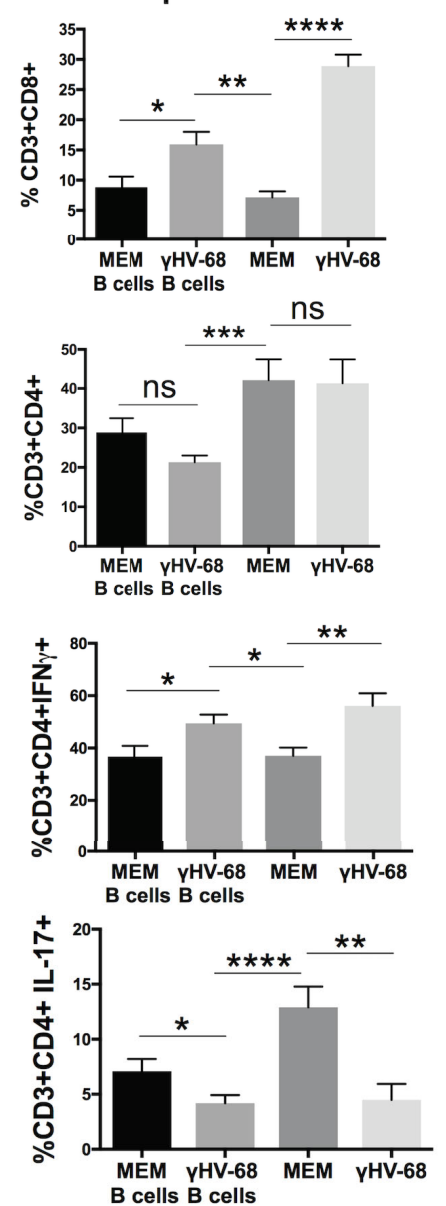

Spleen

G

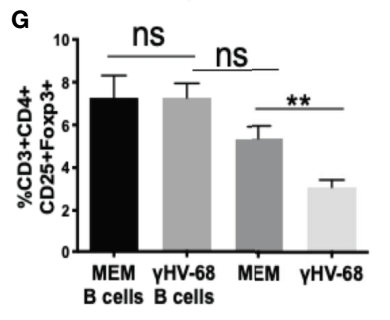

FIGURE 1 | Mice were infected with $\gamma H$ V-68 i.p. 5 weeks p.i. spleens were harvested and CD19 ${ }^{+}$IgD ${ }^{-}$cells were enriched by negative selection. Cells were then transferred into naïve mice ( $\gamma H \mathrm{H}-68 \mathrm{~B}$ cells or MEM B cells). $24 \mathrm{~h}$ after the transfer, EAE was induced. $\gamma H \mathrm{H}-68$ latently infected mice and MEM mice were used as controls. At days 16 to 18 post EAE induction, mice were perfused; brains and spinal cords were harvested and processed to isolate immune infiltrates.

(A) Representative qPCR showing the presence of $\gamma \mathrm{HV}$-68 in enriched CD19+1gD- cells (no amplification in MEM cells). (B) Graph shows EAE scores for naïve mice that received $\gamma H \mathrm{H}-68 \mathrm{~B}$ cells or MEM B cells up to day 17 post induction. (C) Percentage of CD8 ${ }^{+}$infiltrating cells in the brain and spinal cord. (D) Percentage of $\mathrm{CD}^{+}$infiltrating cells in the brain and spinal cord. (E) Percentage of $\mathrm{CD} 3^{+} \mathrm{CD} 4^{+} \mathrm{IFN} \gamma^{+}$in the brain and spinal cord. (F) percentage of $\mathrm{CD} 3^{+} \mathrm{CD} 4^{+} \mathrm{IL}-17^{+}$in the spinal cord. (G) Spleens were harvested and processed to isolate immune infiltrates. Percentage of CD3 ${ }^{+}$cells expressing $\mathrm{CD} 4^{+} \mathrm{CD} 25^{+}$FoxP3 ${ }^{+}$. Three independent experiments with 6 to 24 mice/group. Data analyzed with Student's t-test: ${ }^{\star \star \star *} p<0.0001,{ }^{\star \star *} p<0.001,{ }^{\star \star} p<0.01,{ }^{\star} p<0.05$. ns $=$ not significant.

we induced EAE in mice that received $\mathrm{CD}_{1} 9^{+} \mathrm{IgD}^{-}$cells, we found that the level of Tregs in mice that received $\gamma \mathrm{HV}-68 \mathrm{~B}$ cells remained the same as mice receiving $B$ cells from uninfected mice $(\mathrm{p}=\mathrm{ns})$ (Figure 1G). This suggests that while $\mathrm{CD} 19^{+} \mathrm{IgD}^{-}$ cells from infected mice are able to affect CNS infiltration and cytokine production by infiltrating cells, they do not affect the overall number of Tregs in the periphery.

Overall, these data indicate that $\mathrm{CD}_{1}{ }^{+} \mathrm{IgD}^{-}$cells from latently infected mice are actively interacting with other immune cells and altering the production of cytokines during latency. 


\section{B-Cell Depletion During EAE Moderately Improves EAE Score but Does Not Affect T-Cell Infiltration Into the CNS}

Although the mechanism for why B cell depletion helps stop MS relapses has not yet been identified, it has been suggested that part of its success is due to the depletion of the main reservoir of latent EBV (31). Given the strong effect of B cells in EAE (19-21, 32) we explored whether depleting B cells in $\gamma \mathrm{HV}-68$ infected mice was able to eliminate the effect that memory B cells have during EAE. We depleted B cells in mice latently infected with $\gamma \mathrm{HV}-68(\gamma \mathrm{HV}-68 / \alpha-\mathrm{CD} 20)$ or uninfected controls (MEM/ $\alpha$ CD20) that had an EAE score $\geq 1$ with a murine $\alpha$-CD20 (or PBS as control), we confirmed effective B cell depletion in splenocytes at end point (Figure 2A). When B cells were depleted when EAE symptoms first appeared, $\gamma \mathrm{HV}-68 / \alpha-\mathrm{CD} 20$ mice did not show improvement in their EAE score, and, by day 20, mice had an average score of 2.5 to 3 (Figure 2B and Supplementary 1), even when we observed a significant reduction of the total number of
A

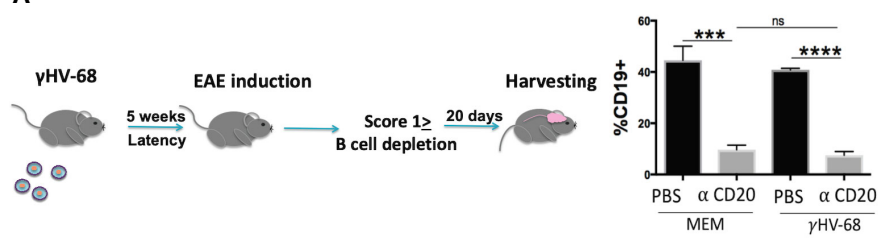

C
Brain

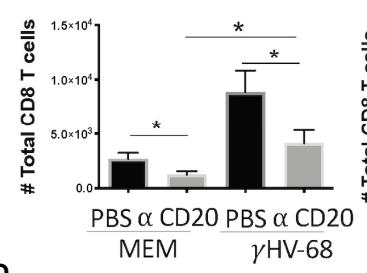

D

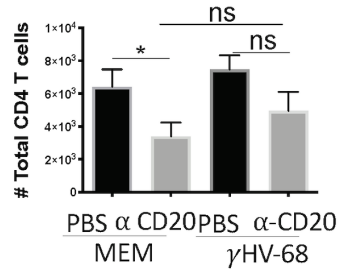

E

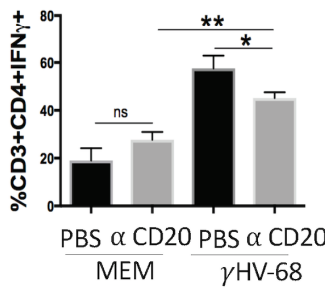

$\mathbf{F}$

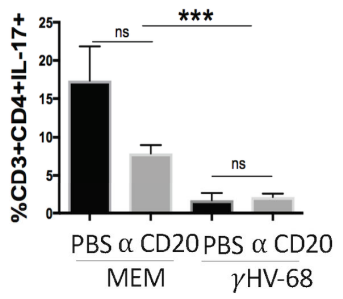

Spinal Cord
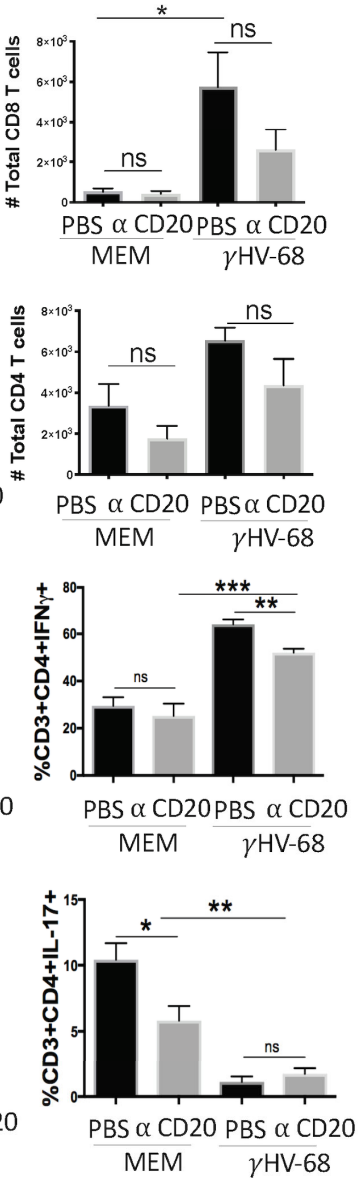

FIGURE 2 | Mice were infected with $\gamma H \mathrm{HV}-68$ or MEM i.p. 5 weeks p.i. EAE was induced. When mice reached a score of $\geq 1$ B cells were depleted with $\alpha$-CD20 i.v. At days 20 to 22 post EAE induction, mice were perfused; brains, spinal cords were harvested and processed to isolate immune infiltrates. (A) B cell depletion workflow. Histogram shows a representative experiment of B population at moment of harvesting. (B) Graph shows EAE scores up to day 23 post induction. (C) Total CD8 ${ }^{+}$infiltrating cells in the brain and spinal cord. (D) Total CD4 ${ }^{+}$infiltrating cells in the brain and spinal cord. (E) Percentage of CD3 ${ }^{+} \mathrm{CD} 4^{+} \mathrm{IFN} \gamma^{+}$. (F) $\mathrm{CD}^{+} \mathrm{CD} 4^{+} \mathrm{IL}-17^{+}$in the brain and spinal cord. Three independent experiments with 6 to 11 mice/group. Data analyzed with Student's t-test: ${ }^{* \star} \mathrm{p}<0.001$, ${ }^{* *} p<0.01,{ }^{*} p<0.05$. ns = not significant. 

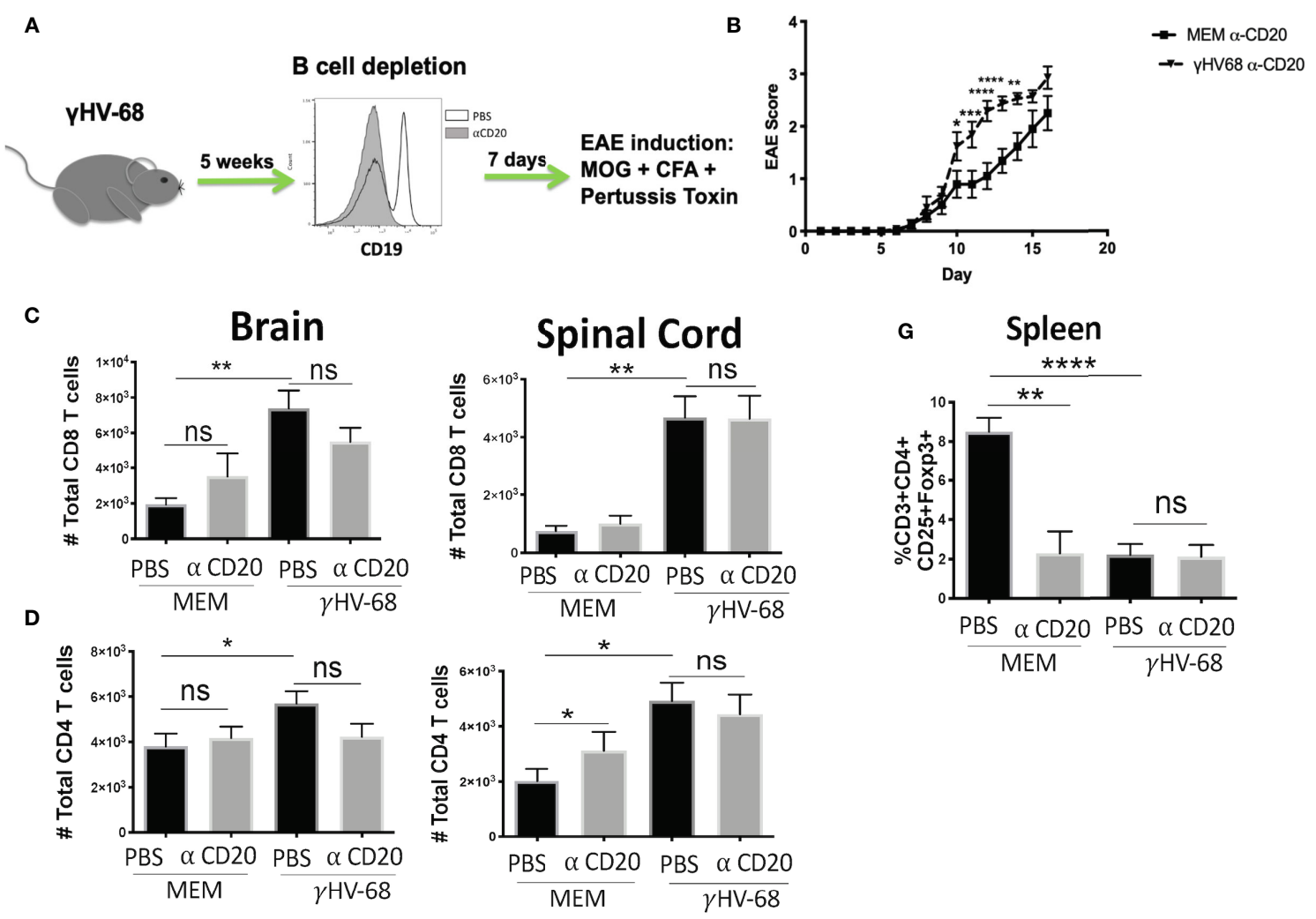

E
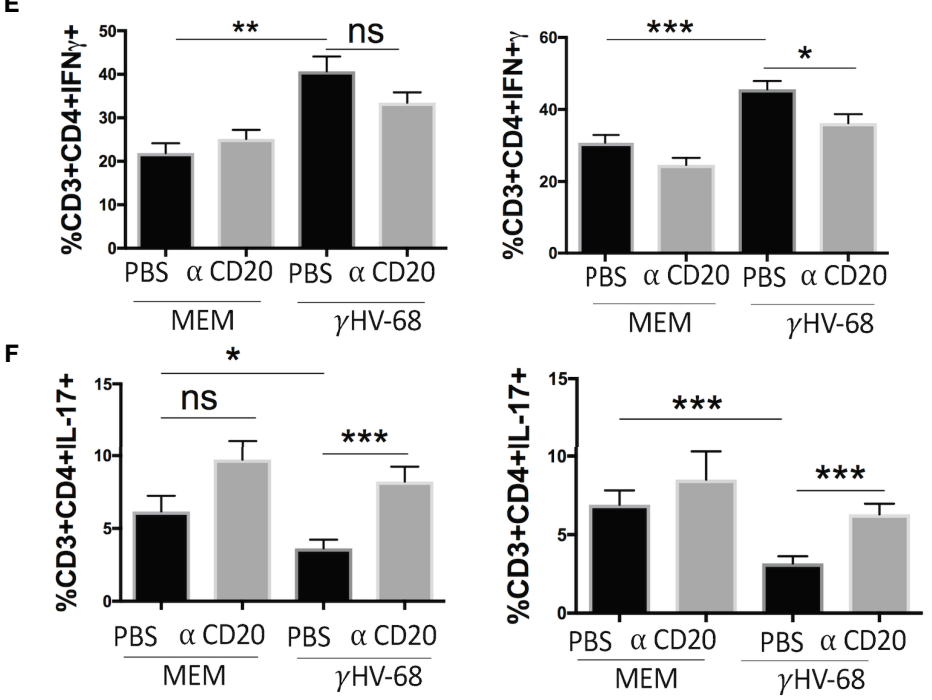

FIGURE 3 | Mice were infected with $\gamma \mathrm{HV}$-68 or MEM i.p. 5 weeks p.i. B cells were depleted with $\alpha$-CD20 i.v. 2 days after depletion EAE was induced. At days 21 to 23 post EAE induction, mice were perfused; brains and spinal cords were harvested and processed to isolate immune infiltrates. (A) Histogram shows a representative experiment of effectiveness of B cell depletion. (B) Graph shows EAE scores up to day 23 post induction. (C) Percentage of CD8 ${ }^{+}$infiltrating cells in the brain and spinal cord. Data analyzed with two-way ANOVA test with Bonferroni's correction for multiple comparisons: ${ }^{\star \star *} \mathrm{p}<0.001$, ${ }^{\star} p<0.05$ (D) Percentage of $\mathrm{CD}^{+}$infiltrating cells in the brain and spinal cord. (E) Percentage of $\mathrm{CD} 3^{+} \mathrm{CD} 4^{+} \mathrm{IFN} \gamma^{+}$and (F) $\mathrm{CD} 3^{+} \mathrm{CD} 4^{+} \mathrm{IL}-17^{+}$in the brain and spinal cord. (G) Spleens were harvested and processed to isolate immune infiltrates. Percentage of $\mathrm{CD} 3^{+}$cells expressing CD $4^{+} \mathrm{CD} 25^{+}$FoxP $3^{+}$. Five independent experiments 20 to 25 mice/group. Data analyzed student's t-test: ${ }^{\star \star \star \star} p<0.0001{ }^{\star \star \star} p<0.001,{ }^{\star \star} p<0.01,{ }^{\star} p<0.05$. ns = not significant.

$\mathrm{CD}^{+} \mathrm{T}$ cells in the brain of $\gamma \mathrm{HV}-68 / \alpha-\mathrm{CD} 20$ mice compared to $\gamma \mathrm{HV}-68 / \mathrm{PBS}$ mice $(\mathrm{p}<0.05)$. This reduction of $\mathrm{CD}^{+} \mathrm{T}$ cell infiltration was not at the same level as MEM mice $(\mathrm{p}<0.05)$
(Figure 2C), and $\mathrm{CD}^{+} \mathrm{T}$ cells remained mostly unchanged $(\mathrm{p}=\mathrm{ns})$ (Figure 2D). Interestingly, we saw a significant reduction in IFN $\gamma$ production in $\mathrm{CD}^{+} \mathrm{T}$ cells in the brain and spinal cord of 
$\gamma \mathrm{HV}-68 / \alpha-\mathrm{CD} 20$ mice compared to $\gamma \mathrm{HV}-68 / \mathrm{PBS}$ mice $(\mathrm{p}<0.01)$ while IL-17 remained downregulated in $\mathrm{CD} 4{ }^{+}$infiltrating $\mathrm{T}$ cells $(\mathrm{p}<0.001)$ (Figures 2E, F). Although IFN $\gamma$ was still upregulated compared to uninfected controls, this slight reduction could explain why $\alpha$-CD20 mice showed a slight improvement in their EAE score right after depletion.

\section{Depletion of B Cells Before EAE Induction Does Ameliorate Symptoms}

In order to determine if EAE enhancement could be stopped by depleting $\mathrm{B}$ cells just prior to EAE induction, we infected mice with $\gamma \mathrm{HV}-68$, waited for 5 weeks p.i, and then depleted B cells with $\alpha$-CD20 antibody or PBS as a control (Figure 3A). Scores remained higher in $\gamma \mathrm{HV}-68 / \alpha-\mathrm{CD} 20$ mice compared to MEM/ $\alpha C D-20$ mice (Figure 3B and Supplementary 2).

Additionally, depletion before EAE induction did not affect the infiltration of $\mathrm{CD}^{+} \mathrm{T}$ cells into the $\mathrm{CNS}(\mathrm{p}=\mathrm{ns}$ ) (Figures $3 \mathrm{C}, \mathrm{D}$ ). When we tested cytokine production by these infiltrating $\mathrm{T}$ cells, we saw that even though a strong production of IFN $\gamma$ in the brain and spinal cord remained present, there was a trend towards downregulation $(\mathrm{p}=\mathrm{ns}$ ) (Figure 3E). More significantly, we observed an upregulation of IL-17 to levels similar to the uninfected control groups $(\mathrm{p}<0.001)$ (Figure 3F). This strongly suggests that while depleting $B$ cells before the onset of symptoms helps to restore some of the balance in cytokine production in $\mathrm{T}$ cell infiltrating cells, it does not stop EAE enhancement. Yet, it may imply that latently infected memory B cells are key to both disease initiation and maintenance. Interestingly, depletion did not allow for the Treg population to recover (Figure 3G) in either the $\gamma \mathrm{HV}-68$ mice or MEM/ $\alpha \mathrm{CD}-20$ groups $(\mathrm{p}<0.0001)$. The latter group has been reported to change as a result of $B$ cell depletion (33).

These results suggest that once EAE is initiated, removal of B cells from $\gamma \mathrm{HV}-68$ infected mice likely only affects disease severity through Th balance skewing.

\section{YHV-68 Latency Establishes a Th1 Precondition That Leads to the Enhancement of EAE}

The fact that B cell depletion only partially altered EAE in $\gamma \mathrm{HV}-68$ infected mice suggests that either not all the virus was cleared with depletion, and/or immune cells in latently infected mice are preprogrammed towards a strong Th1 response. In order to determine whether there was $\gamma \mathrm{HV}-68$ remaining after $\alpha$-CD20 depletion, we quantified the amount of virus present in splenocytes at both points of depletion (Figure 4). We observed that depletion of $B$ cells before EAE induction was highly effective, as all the samples lacked detectable virus. However, B cell depletion after the development of EAE symptoms was not completely effective and a minority of samples retained virus. This suggests that the different effects that we observed in both treatments with $\alpha$-CD20 might be related to the presence/absence of latent virus and/or an effect of latency in the immune system prior to EAE induction. In other words, the effectiveness of treatment is dependent on the time point of depletion relative to the inciting event.

To test if there were any changes occurring in the immune system during latency before EAE induction, we harvested splenocytes from $\gamma \mathrm{HV}-68$ infected mice and determined their IFN $\gamma$ and IL-17 production when they were unspecifically stimulated with PMA/Ionomycin. We observed that while most of the immune cells were present in the same proportion between $\gamma \mathrm{HV}-68$ and MEM mice during latency, cells from $\gamma \mathrm{HV}$ 68 mice were already primed towards a Th1 response, with $\mathrm{CD} 4^{+}$ T cells $(\mathrm{p}<0.01), \mathrm{CD}^{+} \mathrm{T}$ cells $(\mathrm{p}<0.0001), \mathrm{CD} 19^{+} \mathrm{B}$ cells $(\mathrm{p}<$ $0.05), \mathrm{CD} 19^{+} \operatorname{IgD}^{-} \mathrm{B}$ cells $(\mathrm{p}<0.001)$ and $\mathrm{CD} 11 \mathrm{~b}+\mathrm{CD} 11 \mathrm{c}+(\mathrm{p}<$ 0.01 ) producing significantly more IFN $\gamma$ (Figure 5). While the number of $\mathrm{CD} 19^{+} \mathrm{IgD}^{-}$cells decreased in $\gamma \mathrm{HV}-68$ infected mice, they are still potent IFN $\gamma$ producers and are pre-programmed towards both a Th1 response themselves and to drive subsequent strong Th1 responses.

\section{EAE Enhancement Depends on the Presence of B Cells During yHV-68 Infection}

The experiments described above suggest that once $\gamma \mathrm{HV}-68$ latency is established, the immune system of infected mice establishes a precondition that favors a Th1 T cell response. It is known that $\gamma \mathrm{HV}-68$ latency can be established in other cell types in the absence of B cells (34). We explored if the effect of $\gamma \mathrm{HV}-68$ in EAE enhancement was limited to the establishment of latency in B cells or if the potential establishment of latency in other cell types could also lead to EAE enhancement. To investigate this we depleted B cells prior to $\gamma \mathrm{HV}-68$ infection and then, as before, induced EAE 5 weeks after infection (Figure 6A). Importantly, there was no difference in EAE score between $\gamma \mathrm{HV}-68 / \alpha-\mathrm{CD} 20$ mice and the MEM/ $\alpha-\mathrm{CD} 20$ controls similar to what is observed in those mice that have not been infected (Figure 6B and Supplementary 3). Significantly, we observed that the level of infiltration of $\mathrm{CD}^{+} \mathrm{T}$ cells in the brain and spinal cord was similar among $\gamma \mathrm{HV}-68 / \alpha-\mathrm{CD} 20, \mathrm{MEM} / \alpha-\mathrm{CD} 20$ and MEM/PBS mice, with a complete reduction of $\mathrm{CD}^{+} \mathrm{T}$ cell infiltration into the CNS in $\gamma \mathrm{HV}-68$ mice $(\mathrm{p}<0.05)$ (Figures $6 \mathrm{C}, \mathrm{D})$.

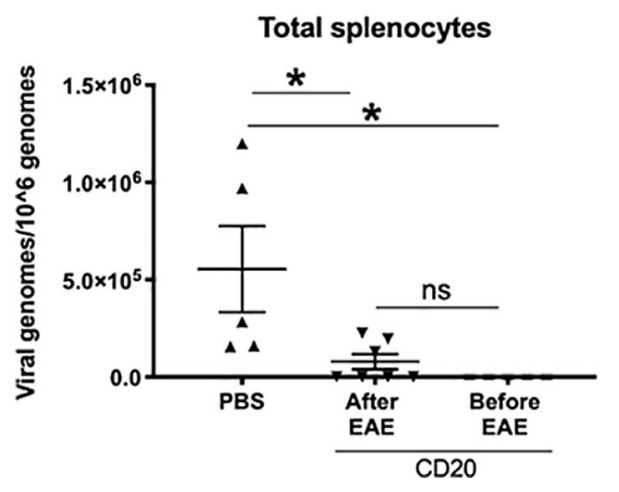

FIGURE 4 | B cells from $\gamma H \mathrm{H}$-68 latently infected mice were depleted with $\alpha$ CD20 i.v. at different time points; before/after EAE induction. Splenocytes were collected at experimental point and qPCR was performed to detect $\gamma \mathrm{HV}$-68. Two independent experiments with 5 to 10 mice/group. Data analyzed with Student's t-test: ${ }^{*} \mathrm{p}<0.05$. ns $=$ not significant. 

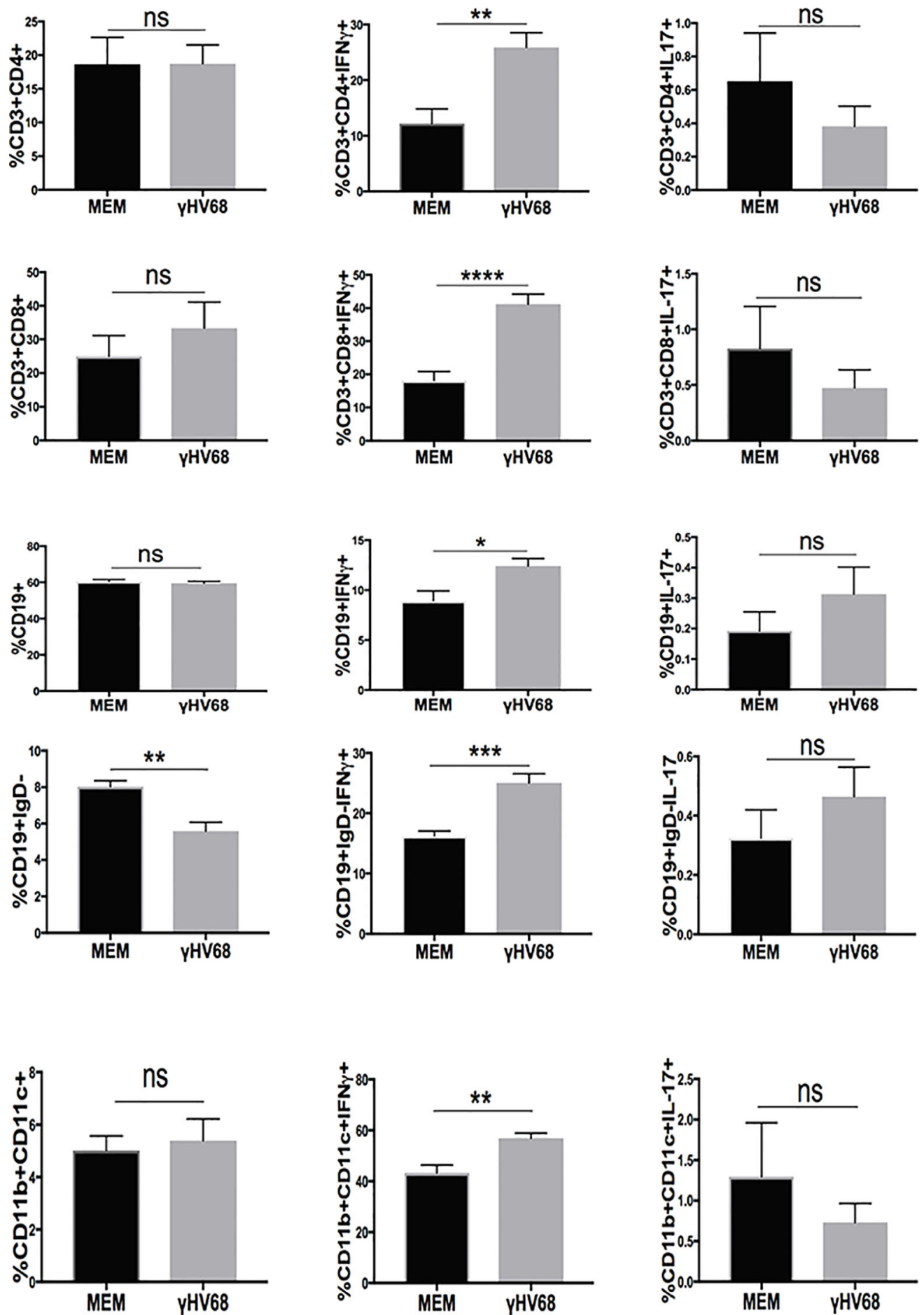

FIGURE 5 Mice were infected with $\gamma H$ H-68 i.p. 5 weeks p.i. spleens were harvested, stimulated with PMA/lonomycin and stained for IFN $\gamma$ and IL-17 in in $\mathrm{CD}^{+} \mathrm{CD}^{+}, \mathrm{CD}^{+} \mathrm{CD}^{+}, \mathrm{CD} 19^{+}, \mathrm{CD} 19^{+} \mathrm{IgD}{ }^{-}, \mathrm{CD} 11 \mathrm{~b}^{+} \mathrm{CD} 11 \mathrm{c}^{+}$cells. Two independent experiments with 6 to 11 mice/group. Data analyzed with Student's t-test: ${ }^{\star \star \star \star *} p<0.0001,{ }^{\star \star \star} p<0.001,{ }^{* \star} p<0.01,{ }^{*} p<0.05$. ns $=$ not significant.

Moreover, we observed similar cytokine production levels from infiltrating $\mathrm{CD}^{+}{ }^{+} \mathrm{T}$ cells between the $\gamma \mathrm{HV}-68 / \alpha-\mathrm{CD} 20$ vs the MEM groups $(\mathrm{p}<0.0001)$, while the $\gamma \mathrm{HV}-68 / \mathrm{PBS}$ group lacking depletion demonstrated strong IFN $\gamma$ production and a marked downregulation in Th17 ( $\mathrm{p}<0.01$ and $\mathrm{p}<0.05)$ (Figures 6E, F). 
A

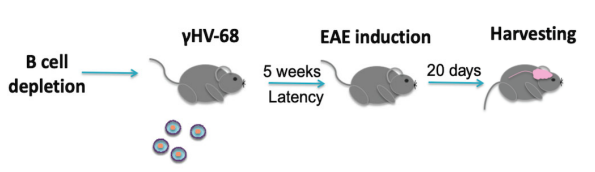

C

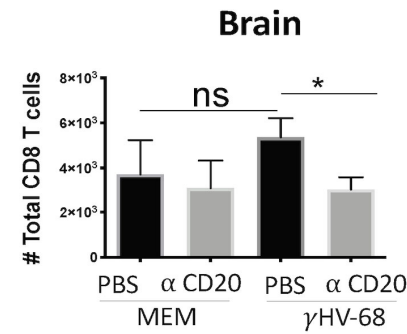

D

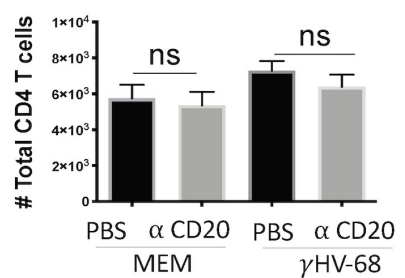

E

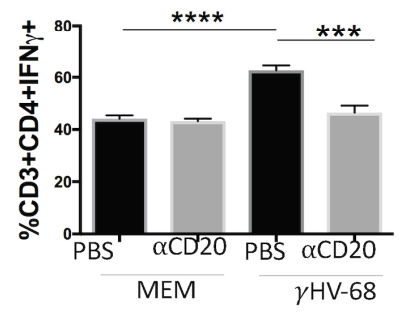

F

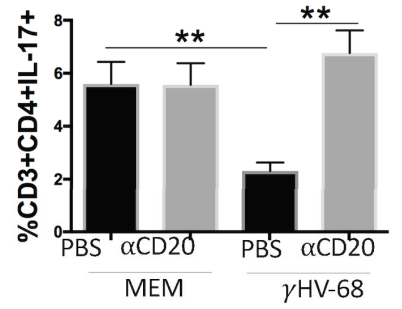

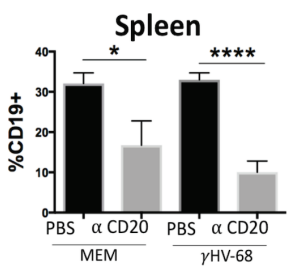

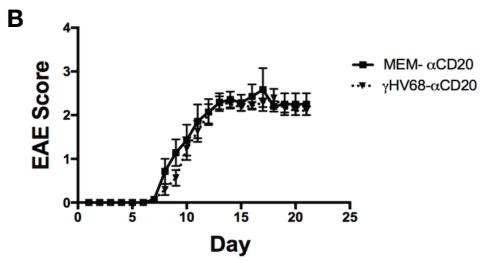

\section{Spinal Cord}

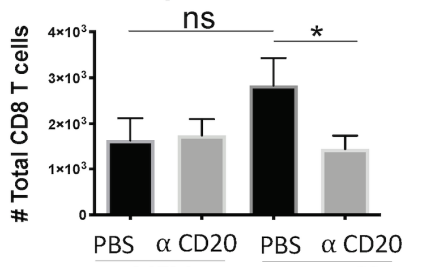

MEM * $\gamma \mathrm{HV}-68$
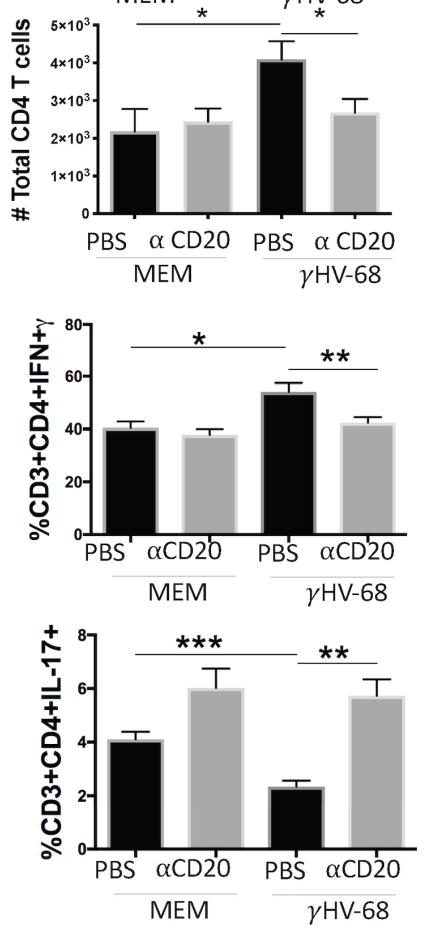

FIGURE 6 | B cells were depleted with $\alpha$-CD20 i.v. 2 days after depletion, mice where infected with $\gamma H$ V-68 or MEM i.p. 5 weeks p.i. EAE was induced. At day 21 post EAE induction, mice were perfused; brains and spinal cords and spleen were harvested and processed to isolate immune infiltrates. (A) Histogram shows $B$ cell levels at experimental end point. (B) Graph shows EAE scores up to day 21 post induction. (C) Total CD8 ${ }^{+}$infiltrating cells in the brain and spinal cord. (D) Total $\mathrm{CD} 4^{+}$infiltrating cells in the brain and spinal cord. Two independent experiments with 6 to 12 per group. (E) Percentage of CD3 ${ }^{+} \mathrm{CD} 4^{+} \mathrm{IFN} \gamma^{+}$and (F) $\mathrm{CD} 3^{+} \mathrm{CD} 4^{+} \mathrm{IL}-$ $17^{+}$in the brain and spinal cord. Two independent experiments with 5 to 12 mice/group. Data analyzed with Student's t-test: ${ }^{\star \star \star *} \mathrm{p}<0.0001,{ }^{* \star *} \mathrm{p}<0.001,{ }^{* \star} \mathrm{p}<$ $0.01,{ }^{\star} \mathrm{p}<0.05$. ns $=$ not significant.

Since memory B cells are the main reservoir of $\gamma \mathrm{HV}-68$ after acute infection, we determined if the virus was able to establish latency in mice without B cells. We quantified $\gamma \mathrm{HV}-68$ in the whole spleen at 35 days p.i. (Figure 7). No virus was detected in the spleen of mice that underwent $B$ cell depletion prior to infection. This is in agreement with other reports where, in the absence of B cells, the virus is less efficient in establishing latency in the spleen but does establish latency in some peritoneal cells and the lungs $(34,35)$. If present, the small number of latently infected cells were not able to enhance EAE. Taken together, our results clearly demonstrate the importance of latently infected B cells in driving a strong Th1 response that directly enhances EAE pathogenesis reminiscent of MS. Importantly, our results also show that for enhanced disease to develop, $\gamma \mathrm{HV}-68$ needs to establish latency in memory B cells. 


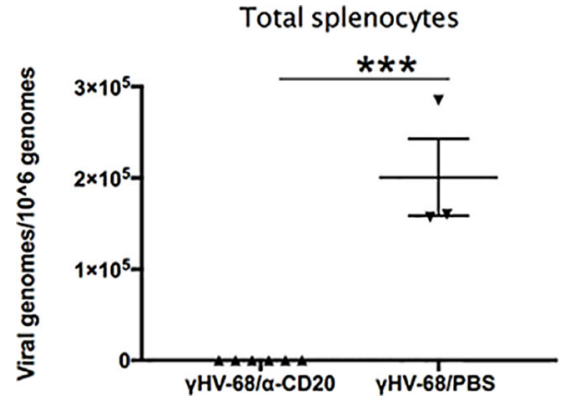

FIGURE 7 | B cells were depleted with $\alpha$-CD20 i.v. 2 days after depletion, mice where infected with $\gamma \mathrm{HV}$-68 or MEM i.p. 5 weeks p.i. EAE was induced Spleens were harvested at 35 days p.i., DNA was extracted, and viral genomes were quantified by qPCR. Graph shows quantification of $\gamma \mathrm{HV}-68$ in mice depleted with $\alpha$-CD20 vs PBS. Two independent experiments with 3 to 6 mice/group. Data analyzed with Student's t-test: ${ }^{\star \star \star} p<0.001$.

\section{DISCUSSION}

In recent years, the unexpected efficiency of $B$ cell depletion therapies has increased interest in the role of B cells in autoimmune diseases, and in MS in particular. To date, the role of $B$ cells in the development of MS is not well understood, but we, and others (31, 36-38), have suggested that the link might be in the latent expression of EBV in memory B cells. Our lab has previously shown

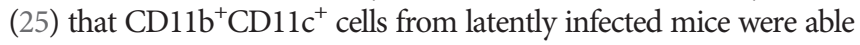
to direct a strong production of IFN $\gamma$. However, these cells were not infected with $\gamma \mathrm{HV}-68$ (25), which suggested that $\mathrm{CD} 11 \mathrm{~b}^{+} \mathrm{CD} 11 \mathrm{c}^{+}$ cells should have been primed by infected B cells during latency.

In this paper, we demonstrated that " $\gamma \mathrm{HV}-68$ latently infected B cells" are indispensable for the enhancement of EAE. The transfer of $\mathrm{CD} 19^{+} \mathrm{IgD}^{-}$cells from $\gamma \mathrm{HV}-68$ mice into naïve mice showed that memory $\mathrm{B}$ cells were actively contributing to directing the strong Th1 response during EAE. While the depletion of $\mathrm{B}$ cells with an $\alpha$-CD20 before and after EAE induction was unsuccessful in decreasing overall disease, we are still able to see high levels of infiltration of $\mathrm{T}$ cells into the CNS, and a high production of IFN $\gamma$. These results suggest that the effects of latency in the immune system can be felt even after the elimination of $\mathrm{B}$ cells and most of the latent virus.

Interestingly, IL-17 is one of the cytokines that changes the most depending on when depletion occurs, in both infected mice and uninfected mice. When $\mathrm{B}$ cell depletion occurred once EAE was induced, we saw an overall downregulation of IL-17. However, when B cell depletion occurred before EAE induction, we saw an overall recovery of IL-17 production, accompanied with a slight downregulation of IFN $\gamma$. This suggests that by eliminating most of the virus before EAE induction, the balance of IFN $\gamma / \mathrm{IL}-17$ was partially restored. There is an interdependent relationship between B cells and Th17. For example, IL-6, a cytokine necessary for IL-17 production, is also a cytokine needed in B cell proliferation (21, 39). Similar to what we observe in B cell depletions before EAE induction, any disturbance in the B cell repertoire in humans and mice seems to also downregulate IL-17 production (40).
Ultimately, the fact that latency in B cells establishes a precondition towards a Th1 response strongly suggests that the only way to effectively eliminate the effects of latency on EAE development is by depleting $\mathrm{B}$ cells before primary infection in order to avoid latency in B cells. This is particularly relevant to MS therapy, since it suggests that in order to have a lasting effect from B cell depletion, initial infection should be avoided. While this is generally not possible with a ubiquitous virus like EBV, its strong link to cancer and other disorders could entertain the possibility of a childhood vaccine to prevent a number of diseases. It would be also interesting to determine whether multiple cycles of $\mathrm{B}$ cell depletion before EAE induction could more thoroughly wane the programming of other immune cells. Defining differential biomarkers of B cells from latently infected mice is essential to targeting disease progression. One possibility is that B cells from $\gamma \mathrm{HV}-68$ have increased antigen presentation capabilities, something that has been observed in memory B cells from MS patients $(41,42)$. Finally, exploring the role of type I IFNs in our model could provide important insight into what kind of signals are being produced by $\mathrm{B}$ cells in infected mice. One possibility is interferon-beta, which has been widely used in the treatment of Relapsing Remitting-MS patients (43), although with limited success (44). Additionally, Type I IFN production is necessary to control reactivation and maintenance of latency of $\gamma \mathrm{HV}-68$ (45) as well as in EBV (46).

In summary, we demonstrated that latently infected memory B cells are critical for driving enhanced disease reminiscent of MS and it is highly likely that EBV may be acting in similar ways in pre-MS and MS patients. We propose that treatments directed at targeting virus or latently infected memory B cells will have more success than current treatments in stopping MS development. The data on B cell depletion therapies is supportive of this notion. However, it also highlights that in order to achieve the highest level of protection against MS is avoiding infection with EBV at all. Hence, the development of a vaccine against EBV might be the only effective way to prevent the effects of EBV in Multiple Sclerosis.

\section{DATA AVAILABILITY STATEMENT}

The original contributions presented in the study are included in the article/Supplementary Material. Further inquiries can be directed to the corresponding author.

\section{ETHICS STATEMENT}

The animal study was reviewed and approved by the Animal Care Committee University of British Columbia.

\section{AUTHOR CONTRIBUTIONS}

$\mathrm{AM}$ and $\mathrm{MH}$ conceived and designed the experiments. AM and IS conducted the experiments. AM and $\mathrm{MH}$ analyzed the results 
and wrote the manuscript. All authors contributed to the article and approved the submitted version.

\section{FUNDING}

This work was supported by a grant from the MS Society of Canada to $\mathrm{MH}$. AM received a PhD fellowship from the MS Society of Canada, Consejo Nacional de Ciencia y

\section{REFERENCES}

1. Collaborators GBDMS. Global, regional, and national burden of multiple sclerosis 1990-2016: a systematic analysis for the Global Burden of Disease Study 2016. Lancet Neurol (2019) 18(3):269-85. doi: 10.1016/S1474-4422(18) 30443-5

2. International Multiple Sclerosis Genetics C. Comprehensive follow-up of the first genome-wide association study of multiple sclerosis identifies KIF21B and TMEM39A as susceptibility loci. Hum Mol Genet (2010) 19(5):953-62. doi: $10.1093 / \mathrm{hmg} / \mathrm{ddp} 542$

3. International Multiple Sclerosis Genetics C, Hafler DA, Compston A, Sawcer S, Lander ES, Daly MJ, et al. Risk alleles for multiple sclerosis identified by a genomewide study. New Engl J Med (2007) 357(9):851-62. doi: 10.1056/ NEJMoa073493

4. Maver A, Lavtar P, Ristic S, Stopinsek S, Simcic S, Hocevar K, et al. Identification of rare genetic variation of NLRP1 gene in familial multiple sclerosis. Sci Rep (2017) 7(1):3715. doi: 10.1038/s41598-017-03536-9

5. Wang Z, Sadovnick AD, Traboulsee AL, Ross JP, Bernales CQ, Encarnacion M, et al. Nuclear Receptor NR1H3 in Familial Multiple Sclerosis. Neuron (2016) 90(5):948-54. doi: 10.1016/j.neuron.2016.04.039

6. Munger KL, Zhang SM, O'Reilly E, Hernan MA, Olek MJ, Willett WC, et al. Vitamin D intake and incidence of multiple sclerosis. Neurology (2004) 62 (1):60-5. doi: 10.1212/01.WNL.0000101723.79681.38

7. Hernan MA, Olek MJ, Ascherio A. Cigarette smoking and incidence of multiple sclerosis. Am J Epidemiol (2001) 154(1):69-74. doi: 10.1093/aje/ 154.1.69

8. Warner HB, Carp RI. Multiple sclerosis and Epstein-Barr virus. Lancet. (1981) 2(8258):1290. doi: 10.1016/S0140-6736(81)91527-0

9. Olsson T, Barcellos LF, Alfredsson L. Interactions between genetic, lifestyle and environmental risk factors for multiple sclerosis. Nat Rev Neurol (2017) 13(1):25-36. doi: 10.1038/nrneurol.2016.187

10. Tarlinton RE, Martynova E, Rizvanov AA, Khaiboullina S, Verma S. Role of Viruses in the Pathogenesis of Multiple Sclerosis. Viruses. (2020) 12(6):643. doi: $10.3390 / \mathrm{v} 12060643$

11. Kadowaki A, Quintana FJ. The Gut-CNS Axis in Multiple Sclerosis. Trends Neurosci (2020) 43(8):622-34. doi: 10.1016/j.tins.2020.06.002

12. Pakpoor J, Disanto G, Gerber JE, Dobson R, Meier UC, Giovannoni G, et al. The risk of developing multiple sclerosis in individuals seronegative for Epstein-Barr virus: a meta-analysis. Mult Scler (2013) 19(2):162-6. doi: $10.1177 / 1352458512449682$

13. Fernandez-Menendez S, Fernandez-Moran M, Fernandez-Vega I, PerezAlvarez A, Villafani-Echazu J. Epstein-Barr virus and multiple sclerosis. From evidence to therapeutic strategies. J Neurol Sci (2016) 361:213-9. doi: 10.1016/j.jns.2016.01.013

14. Alfredsson L, Olsson T. Lifestyle and Environmental Factors in Multiple Sclerosis. Cold Spring Harb Perspect Med (2019) 9(4):a028944. doi: 10.1101/ cshperspect.a028944

15. Marrodan M, Alessandro L, Farez MF, Correale J. The role of infections in multiple sclerosis. Multiple Sclerosis (2019) 25(7):891-901. doi: 10.1177/ 1352458518823940

16. Handel AE, Williamson AJ, Disanto G, Handunnetthi L, Giovannoni G, Ramagopalan SV. An updated meta-analysis of risk of multiple sclerosis following infectious mononucleosis. PloS One (2010) 5(9):e12496. doi: 10.1371/journal.pone.0012496
Tecnologia (CONACyT) and The American Association of Immunologists.

\section{SUPPLEMENTARY MATERIAL}

The Supplementary Material for this article can be found online at: https://www.frontiersin.org/articles/10.3389/fimmu.2020. 584297/full\#supplementary-material

17. Bar-Or A, Pender MP, Khanna R, Steinman L, Hartung HP, Maniar T, et al. Epstein-Barr Virus in Multiple Sclerosis: Theory and Emerging Immunotherapies. Trends Mol Med (2020) 26(3):296-310. doi: 10.1016/ j.molmed.2019.11.003

18. Probstel AK, Sanderson NS, Derfuss T. B Cells and Autoantibodies in Multiple Sclerosis. Int J Mol Sci (2015) 16(7):16576-92. doi: 10.3390/ijms160716576

19. Lehmann-Horn K, Schleich E, Hertzenberg D, Hapfelmeier A, Kumpfel T, von Bubnoff $\mathrm{N}$, et al. Anti-CD20 B-cell depletion enhances monocyte reactivity in neuroimmunological disorders. J Neuroinflammation (2011) 8:146. doi: 10.1186/1742-2094-8-146

20. Weber MS, Prod'homme T, Patarroyo JC, Molnarfi N, Karnezis T, LehmannHorn $\mathrm{K}$, et al. B-cell activation influences T-cell polarization and outcome of anti-CD20 B-cell depletion in central nervous system autoimmunity. Ann Neurol (2010) 68(3):369-83. doi: 10.1002/ana.22081

21. Barr TA, Shen P, Brown S, Lampropoulou V, Roch T, Lawrie S, et al. B cell depletion therapy ameliorates autoimmune disease through ablation of IL-6producing B cells. J Exp Med (2012) 209(5):1001-10. doi: 10.1084/ jem.20111675

22. Parker Harp CR, Archambault AS, Sim J, Ferris ST, Mikesell RJ, Koni PA, et al. B cell antigen presentation is sufficient to drive neuroinflammation in an animal model of multiple sclerosis. J Immunol (Baltimore Md 1950) (2015) 194(11):5077-84. doi: 10.4049/jimmunol.1402236

23. Molnarfi N, Schulze-Topphoff U, Weber MS, Patarroyo JC, Prod'homme T, Varrin-Doyer M, et al. MHC class II-dependent B cell APC function is required for induction of CNS autoimmunity independent of myelinspecific antibodies. J Exp Med (2013) 2102013:2921-37. doi: 10.1084/ jem.20130699

24. van Langelaar J, Rijvers L, Smolders J, van Luijn MM. B and T Cells Driving Multiple Sclerosis: Identity, Mechanisms and Potential Triggers. Front Immunol (2020) 11:760. doi: 10.3389/fimmu.2020.00760

25. Casiraghi C, Shanina I, Cho S, Freeman ML, Blackman MA, Horwitz MS. Gammaherpesvirus latency accentuates EAE pathogenesis: relevance to Epstein-Barr virus and multiple sclerosis. PloS Pathog (2012) 8(5):e1002715. doi: 10.1371/journal.ppat.1002715

26. Doherty PC, Tripp RA, Hamilton-Easton AM, Cardin RD, Woodland DL, Blackman MA. Tuning into immunological dissonance: an experimental model for infectious mononucleosis. Curr Opin Immunol (1997) 9(4):47783. doi: 10.1016/S0952-7915(97)80098-2

27. Casiraghi C, Marquez AC, Shanina I, Horwitz MS. Latent virus infection upregulates CD40 expression facilitating enhanced autoimmunity in a model of multiple sclerosis. Sci Rep (2015) 5:13995. doi: 10.1038/srep13995

28. Willer DO, Speck SH. Long-term latent murine Gammaherpesvirus 68 infection is preferentially found within the surface immunoglobulin Dnegative subset of splenic B cells in vivo. J Virol (2003) 77(15):8310-21. doi: 10.1128/JVI.77.15.8310-8321.2003

29. Kenney SC, Mertz JE. Regulation of the latent-lytic switch in Epstein-Barr virus. Semin Cancer Biol (2014) 26:60-8. doi: 10.1016/j.semcancer.2014.01.002

30. Alcoser SY, Kimmel DJ, Borgel SD, Carter JP, Dougherty KM, Hollingshead MG. Real-time PCR-based assay to quantify the relative amount of human and mouse tissue present in tumor xenografts. BMC Biotechnol (2011) 11:124. doi: 10.1186/1472-6750-11-124

31. Ascherio A, Munger KL, Lennette ET, Spiegelman D, Hernan MA, Olek MJ, et al. Epstein-Barr virus antibodies and risk of multiple sclerosis: a prospective study. Jama (2001) 286(24):3083-8. doi: 10.1001/jama.286.24.3083 
32. Matsushita T, Yanaba K, Bouaziz JD, Fujimoto M, Tedder TF. Regulatory B cells inhibit EAE initiation in mice while other B cells promote disease progression. J Clin invest (2008) 118(10):3420-30. doi: 10.1172/JCI36030

33. Lykken JM, DiLillo DJ, Weimer ET, Roser-Page S, Heise MT, Grayson JM, et al. Acute and chronic B cell depletion disrupts CD4+ and CD8+ T cell homeostasis and expansion during acute viral infection in mice. J Immunol (Baltimore Md 1950) (2014) 193(2):746-56. doi: 10.4049/jimmunol.1302848

34. Weck KE, Kim SS, Virgin HI, Speck SH. B cells regulate murine gammaherpesvirus 68 latency. J Virol (1999) 73(6):4651-61. doi: 10.1128/ JVI.73.6.4651-4661.1999

35. Usherwood EJ, Stewart JP, Robertson K, Allen DJ, Nash AA. Absence of splenic latency in murine gammaherpesvirus 68 -infected B cell-deficient mice. J Gen Virol (1996) 77( Pt 11):2819-25. doi: 10.1099/0022-1317-77-11-2819

36. Pender MP, Burrows SR. Epstein-Barr virus and multiple sclerosis: potential opportunities for immunotherapy. Clin Trans Immunol (2014) 3(10):e27. doi: 10.1038/cti.2014.25

37. t Hart BA, Jagessar SA, Haanstra K, Verschoor E, Laman JD, Kap YS. The Primate EAE Model Points at EBV-Infected B Cells as a Preferential Therapy Target in Multiple Sclerosis. Front Immunol (2013) 4:145. doi: 10.3389/ fimmu.2013.00145

38. Márquez AC, Horwitz MS. The Role of Latently Infected B Cells in CNS Autoimmunity. Front Immunol (2015) 6:544. doi: 10.3389/fimmu. 2015.00544

39. Wilson NJ, Boniface K, Chan JR, McKenzie BS, Blumenschein WM, Mattson JD, et al. Development, cytokine profile and function of human interleukin 17producing helper T cells. Nat Immunol (2007) 8(9):950-7. doi: 10.1038/ni1497

40. Barbosa RR, Silva SP, Silva SL, Melo AC, Pedro E, Barbosa MP, et al. Primary B-cell deficiencies reveal a link between human IL-17-producing CD4 T-cell homeostasis and B-cell differentiation. PloS One (2011) 6(8):e22848. doi: 10.1371/journal.pone.0022848

41. Harp CT, Ireland S, Davis LS, Remington G, Cassidy B, Cravens PD, et al. Memory B cells from a subset of treatment-naive relapsing-remitting multiple sclerosis patients elicit CD4(+) T-cell proliferation and IFN-gamma production in response to myelin basic protein and myelin oligodendrocyte glycoprotein. Eur J Immunol (2010) 40(10):2942-56. doi: 10.1002/ eji.201040516

42. Duddy M, Niino M, Adatia F, Hebert S, Freedman M, Atkins H, et al. Distinct effector cytokine profiles of memory and naive human B cell subsets and implication in multiple sclerosis. J Immunol (Baltimore Md 1950) (2007) 178 (10):6092-9. doi: 10.4049/jimmunol.178.10.6092

43. Rudick RA, Goodkin DE, Jacobs LD, Cookfair DL, Herndon RM, Richert JR, et al. Impact of interferon beta-1a on neurologic disability in relapsing multiple sclerosis. The Multiple Sclerosis Collaborative Research Group (MSCRG). Neurology (1997) 49(2):358-63. doi: 10.1212/wnl.49.2.358

44. Jones JL, Coles AJ. New treatment strategies in multiple sclerosis. Exp Neurol (2010) 225(1):34-9. doi: 10.1016/j.expneurol.2010.06.003

45. Barton ES, Lutzke ML, Rochford R, Virgin H. Alpha/beta interferons regulate murine gammaherpesvirus latent gene expression. J Virol (2005) 79 (22):14149-60. doi: 10.1128/JVI.79.22.14149-14160.2005

46. Salamon D, Adori M, Ujvari D, Wu L, Kis LL, Madapura HS, et al. Latency type-dependent modulation of Epstein-Barr virus-encoded latent membrane protein 1 expression by type I interferons in B cells. J Virol (2012) 86(8):47017. doi: 10.1128/JVI.06829-11

Conflict of Interest: The authors declare that the research was conducted in the absence of any commercial or financial relationships that could be construed as a potential conflict of interest.

Copyright (c) 2020 Márquez, Shanina and Horwitz. This is an open-access article distributed under the terms of the Creative Commons Attribution License (CC BY). The use, distribution or reproduction in other forums is permitted, provided the original author(s) and the copyright owner(s) are credited and that the original publication in this journal is cited, in accordance with accepted academic practice. No use, distribution or reproduction is permitted which does not comply with these terms. 